\title{
FLOWERING BIOLOGY OF THREE TAXA OF THE GENUS Scilla L. (HYACINTHACEAE) AND FLOWER VISITATION BY POLLINATING INSECTS
}

\author{
Beata Żuraw \\ University of Life Sciences in Lublin, Department of Botany, Akademicka 15, 20-950 Lublin, Poland, \\ e-mail: beata.zuraw@up.lublin.pl
}

Received: 09.10.2010

\begin{abstract}
Squill of the family Hyacinthaceae is a small bulb perennial. The present study on flowering and pollination of Scilla sibirica Andr., S. sibirica 'Alba', and S. bifolia L. was conducted in the years 1995, 1997, and 1999 in the Botanical Garden of the Maria Curie-Skłodowska University in Lublin. The plants flowered from the end of March until the middle of May. The duration of flowering of individual taxa was similar and it averaged 20 days (Scilla sibirica), 21 days (S. sibirica 'Alba'), and 23 days ( $S$. bifolia). The opening of flower buds always started around 9.00 am and lasted, depending on the taxon, until 3.00 $\mathrm{pm}$ (Scilla sibirica 'Alba'), $4.00 \mathrm{pm}$ (S. bifolia), and $5.00 \mathrm{pm}(S$. sibirica). The flowers were visited by bees (Apoidea), primarily the honey bee (Apis mellifera L.), bumblebee (Bombus L.), and solitary bees. Numerous honey bee foragers were observed; they bit through the anther walls and even attempted to open still closed flower buds in order to reach the pollen.
\end{abstract}

Key words: squill (Scilla L.), Hyacinthaceae, flowering rate, insect visitation

\section{INTRODUCTION}

The genus squill (Scilla L.) of the family Hyacinthaceae numbers 50 species spread across Eurasia and southern Africa. Its plants produce an oval or spherical bulb from which basal leaves grow. Flowers are borne singly or are clustered in racemes. Pink, violet, blue, or white coloured tepals are single-veined and are borne in 2 whorls with 3 tepals in each. 6 stamens and one three-chambered pistil with septal nectaries are located in the flowers. The fruit is a capsule $(\mathrm{S} \mathrm{z}$ a f e $\mathrm{r}$ et al. 1969; W a t s o n and Dallwitz, 1992; P f o s ser and Speta, 1999).

An advantage of many representatives of the genus Scilla is the early flowering time. Due to their colourful and original flowers, the species and varieties of this genus are recommended for cultivation in rock gardens as well as for group plantings under shrubs and on lawns. The most known species that is recommended for cultivation is Scilla sibirica ( $\mathrm{Krause}$, 1987, 1992; Marcinkowski, 1991; Osvald, 1992). Nearly all species are suitable for accelerated indoor cultivation (S z l a c h e t k a, 1993). In Poland Scilla bifolia is a species that is found in natural plant communities of the Eastern Carpathians (S tru mil ło, 1883; Tyniecki, 1912; S z a fer et al. 1969; Mirek et al. 2002), while Scilla sibirica is grown as an ornamental garden plant, which sometimes runs wild (M i re k et al. 2002).

The above mentioned species are not only ornamental plants, but they are also forage plants for pollinating insects, providing to them nectar and pollen. The flowers of Scilla bifolia are readily visited by the honey bee (Apis mellifera L.), which is noted by many authors (J a b ł o ń s k i , 1978, 1986; P i e t k o v, 1979; Li piński, 1982; W a rak o m ska, 1987). According to Kulije v (1952) and Ruszkows k i $(1969,1971)$, Scilla sibirica is considered to be an important forage plant for the bumblebee (Bombus L.). The mason bee (Osmia Pz.) and the hairy-footed flower bee (Anthophora L.) gather pollen from the flowers of this species (Ruszkowski, 1966, 1971; Ruszkowski and Żak, 1969; Ruszkowski and Biliński, 1986). Early spring forage plants are of great importance for the proper development of bee colonies (J a b ł oń s k i 1978, 1986; L i p i ń s k i 1982), hence squill, which blooms during the period of March and April, can have not only the ornamental value, but also the apicultural one. 
The aim of the present study was to determine the flowering rate and the rate of visitation to three taxa of the genus Scilla L. by pollinating insects.

\section{MATERIALS AND METHODS}

Two species were covered by our observations: Siberian squill (Scilla sibirica Andr.) and Alpine squill (Scilla bifolia L.), but also a white flowering variety of Siberian squill - 'Alba' (Scilla sibirica 'Alba'). The studied plants were cultivated in the Botanical Garden of the Maria Curie-Skłodowska University in Lublin. Scilla bifolia L. specimens were growing on the slopes and at the bottom of a gully, forming the ground cover of an old park. The plants of the genus Scilla sibirica Andr. covered the surface of lawns and under shrubs, whereas the plants of the variety Scilla sibirica 'Alba' were growing in a small clearing in a rock garden. The plants under study required no tending. Mineral and organic fertilization was not applied, either. The soil in all study sites was compact and clayey, developed on loess substrate with a $\mathrm{pH}$ of 6-7. The perennials were not protected for winter.

The seasonal flowering rate of Scilla sibirica Andr., that is, the number of opening flowers per unit area in successive days of the flowering period, was investigated in the years 1995 and 1997. To this end, 4 plots were marked out, each with an area of $50 \times 50 \mathrm{~cm}$, which was $1 \mathrm{~m}^{2}$ in total. Within this designated area, every day at $6.00 \mathrm{pm}$ the flowers that had opened during the day were counted and removed, from the beginning to the end of flowering. The sum of flowers from the total area of $1 \mathrm{~m}^{2}$ formed the basis for the calculation of the percentage assigned to each day of the flowering period of the plants.

Seasonal observations of flower visitation by pollinating insects were conducted in the same plots. For this purpose, every day at $2.00 \mathrm{pm}$, that is, during the time of the greatest density of insects on the plants, honey bee foragers foraging on the flowers were counted. The sum of insects counted was the basis for the calculation of the percentage assigned to each day of the flowering period of the plants.

The daily rate of flower opening was determined by counting freshly opened buds every hour (from $8.00 \mathrm{am}$ to $6.00 \mathrm{pm}$ Eastern European Time) for three days during the full bloom stage. At the same time, observations of the daily pattern of flower visitation by the honey bee were carried out.

\section{RESULTS}

Flowering. The squill flowers attracted pollinating insects by the colour of their perianth (violet, sapphire, white) (Figs 1, 2), their characteristic scent, and the nectar that was secreted already in the bud.
The nectar-secreting tissue in the flowers of Scilla is located in three septal nectaries; the secretion exuded outside the pistil accumulated in the spaces between the ovary and the staminal filaments. After the anthers were empty of pollen, the style of the pistil elongated and changed colour from sapphire to white in the flowers of Scilla sibirica and from violet to white in the flowers of S. bifolia.

The investigated perennials produced from 1 up to 3 inflorescence stems from a bulb, and from several (Scilla sibirica, S. sibirica 'Alba') up to over a dozen (S. bifolia) flowers appeared on these shoots (Fig. 1, Table 1). The duration of flowering in the plants under investigation did not differ significantly in individual taxa.

The plants of Scilla bifolia bloomed earliest, at the end of March or in the first days of April (Fig. 3). Scilla sibirica bloomed after several days, whereas S. sibirica 'Alba' entered the flowering stage latest, thereby extending the early spring source of forage even until the first decade of May. The weather pattern in the spring of a particular year affected the time and duration of flowering of the plants under study.

During flowering of Scilla sibirica, periods of adverse weather conditions occurred every year, with temperature falls down to even $-6^{\circ} \mathrm{C}$ (Figs 4, 5). A distinct increase in the number of open flower buds was observed with sunshine duration of 10-12 hours. In general, in 1995 two periods of increased flowering of Scilla sibirica could be observed, on 6 and 15 April. On these days, the total number of flowers opened during the day accounted for ca. $15 \%$ of the total number of flowers that bloomed throughout the entire flowering period (Fig. 4). In 1997 the flowering pattern in the investigated species was even. There were noted regular small increases in the flowering rate, reaching up to ca. $10 \%$ of the total number of flowers (Fig. 5).

Flower opening in all the taxa under study started around 9.00 am (Fig. 6). Buds of Scilla sibirica 'Alba' and S. bifolia opened up mainly before noon, whereas buds of $S$. sibirica opened up evenly throughout the whole day. A slight inhibition in the flowering dynamics around $2.00 \mathrm{pm}$ could have resulted from the temporary shading of the plants by high pine trees growing on the southern side of the study area. The inhibition in bud opening occurred earliest in the variety S. sibirica 'Alba', already at $3.00 \mathrm{pm}$, then in S. bifolia at $4.00 \mathrm{pm}$, and latest in S. sibirica - at $5.00 \mathrm{pm}$.

The flower life span in the studied taxa was from 3 to 10 days. The flowers definitely responded to temperature changes in the environment. The perianth closed every day in afternoon hours and opened in the morning around $9.00 \mathrm{am}$.

Flower visitation by pollinating insects. The seasonal rate of flower visitation by the honey bee, observed in 1995, was correlated positively with the 
rate of flower opening (Fig. 4). Low temperature was a factor that particularly reduced flower visitation by insects.

During the day, the flowers of Scilla sibirica were visited regularly by the honey bee from $9.00 \mathrm{am}$ to $4.00 \mathrm{pm}$ (Fig. 6). In the morning hours, the insects collected nectar from the flowers that had opened up on the previous day. The bees extracted pollen from not fully open pollen chambers. The colour of pollen loads formed by the bees (the average weight of a pair of pollen loads was $6.5 \mathrm{mg}$ ) ranged from dark sapphire to navy blue (Fig. 2A). Solitary bees and bumblebees were also observed on the flowers between $11.00 \mathrm{am}$ and $3.00 \mathrm{pm}$.

The flowers of the variety Scilla sibirica 'Alba' were visited most intensively during late morning hours between 9.00 and 11.00 am (Fig. 6). Reduced insect visitation was observed after $12.00 \mathrm{am}$, which could have resulted from the fact that the site in which the investigated plants were located was shaded by conifers growing on its southern side. Pollen loads produced by the foragers were crème-coloured (Fig. 2B).

The daily peak of insect visitation to the flowers of Scilla bifolia was at 11.00 am (Fig. 6). Nectar foragers were observed during morning hours (from 8.00 to 10.00), whereas from 10.00 am bees with pollen loads were noticed (Fig. 2C). The insects worked with such great energy that the stamen heads frequently became detached from the filaments. Honey bees often made an attempt to open flower buds (Fig. 2C). The pollen mass, formed into pollen loads, was coloured dark violet by anthocyanins escaping from the damaged tissues of the anthers. In addition to the honey bee, solitary bees were observed foraging on the flowers of S. bifolia between 12.00 am and $3.00 \mathrm{pm}$.
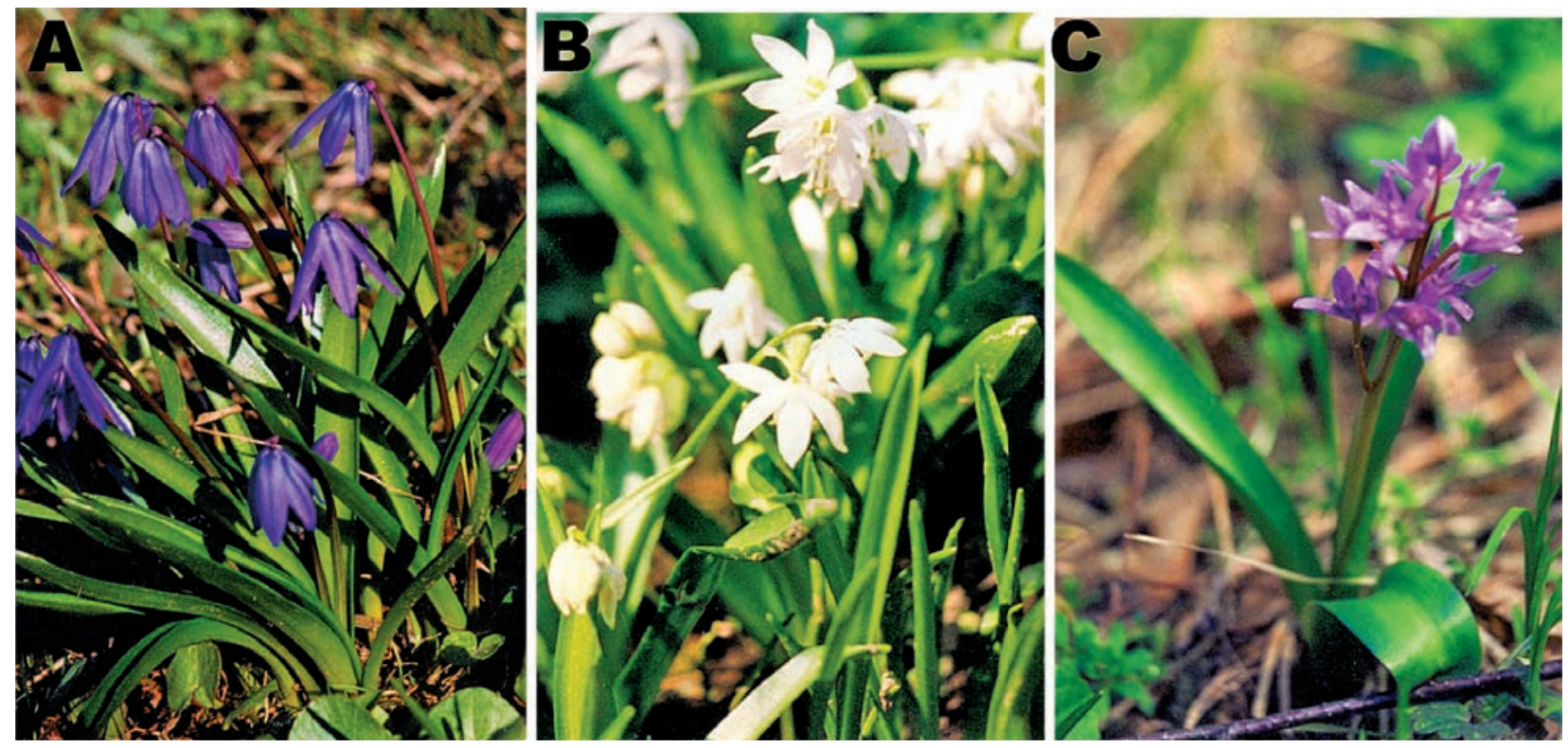

Fig. 1. Flowering specimens of the studied species:

A - Scilla sibirica Andr. (x 0.5); B - Scila sibirica 'Alba' (x 0.5); C - Scilla bifolia L. (x 0.3).
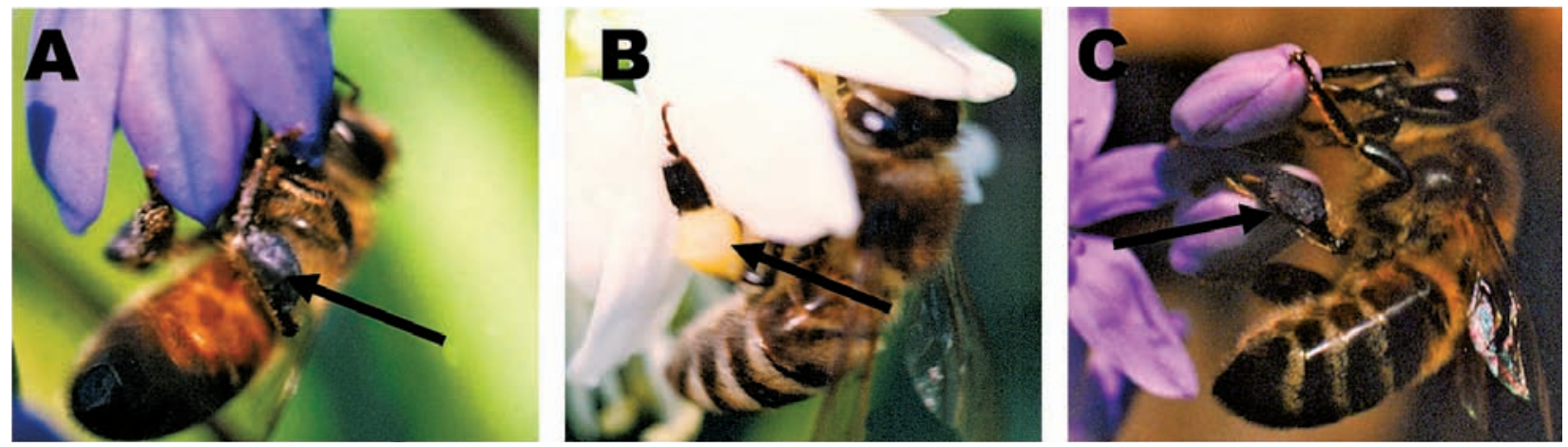

Fig. 2. Pollen foragers of the honey bee (Apis mellifera $\mathrm{L}$.) on the flowers of the studied plants:

A - Scilla sibirica Andr. (x 3.5); B - Scila sibirica 'Alba' (x 3.5); C - Scilla bifolia L. (x 3.5), pollen loads. 


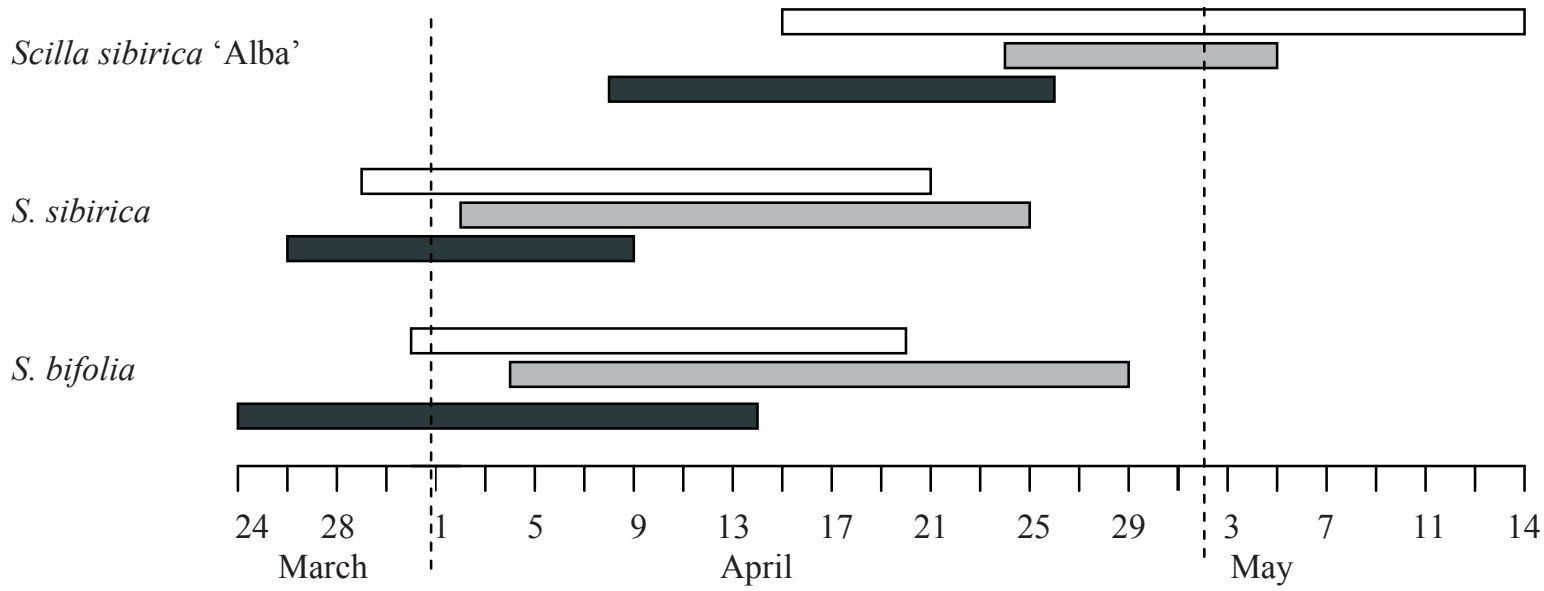

Fig. 3. The flowering calendar of the studied taxa in different years:

$\square$ - 1995;

- 1997; $\square-1999$.

Table 1

The duration and abundance of flowering of squill.

\begin{tabular}{cccc}
\hline Species, variety & Year of study & Number of flowering days & Flowers $\cdot$ inflorescence $^{-1}$ \\
\hline \multirow{3}{*}{ S. bifolia L. } & 1995 & 16 & 3.7 \\
& 1997 & 24 & 6.3 \\
& 1999 & 20 & 4.3 \\
& Average & 20.0 & 4.8 \\
\hline & 1995 & 16 & 3.6 \\
S. sibirica Andr. & 1997 & 11 & 1.7 \\
& 1999 & 29 & 2.5 \\
& Average & 18.7 & 2.6 \\
\hline & 1995 & 14 & 3.5 \\
& 1997 & 22 & 4.1 \\
& 1999 & 22 & 1.7 \\
& Average & 19.3 & 3.1 \\
\hline
\end{tabular}
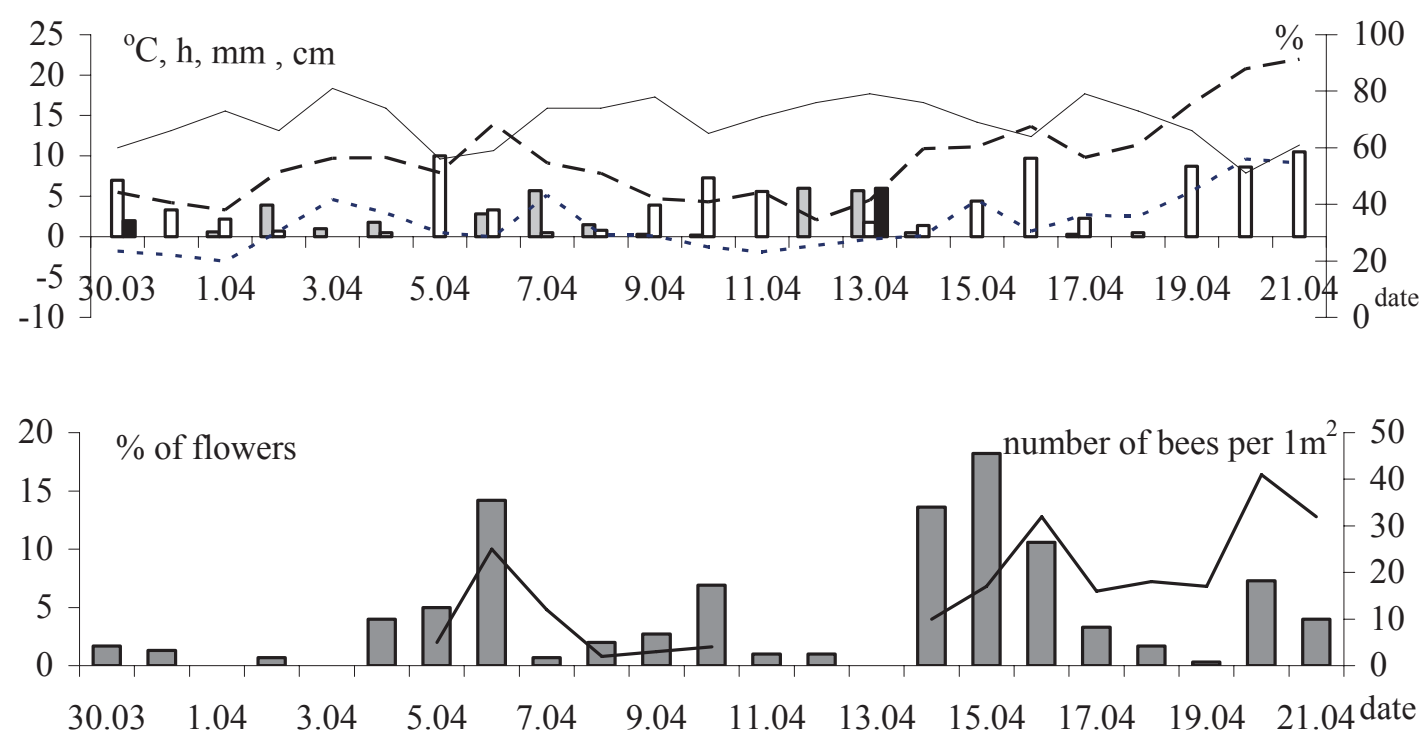

Fig. 4. The seasonal flowering rate of Scilla sibirica L. and visitation by honey bee foragers relative to weather conditions in 1995.

$\square$ - rainfall in $\mathrm{mm}$; $\square$ - snowfall in $\mathrm{cm} ; \square$ - sunshine duration in hours;

- air relative humidity in $\% ; \ldots . . . . .-$ min. temp. in ${ }^{\circ} \mathrm{C} ;---\max$. temp. in ${ }^{\circ} \mathrm{C}$

$\square-\%$ of flowers opened on a particular day, -- number of bees per $1 \mathrm{~m}^{2}$. 

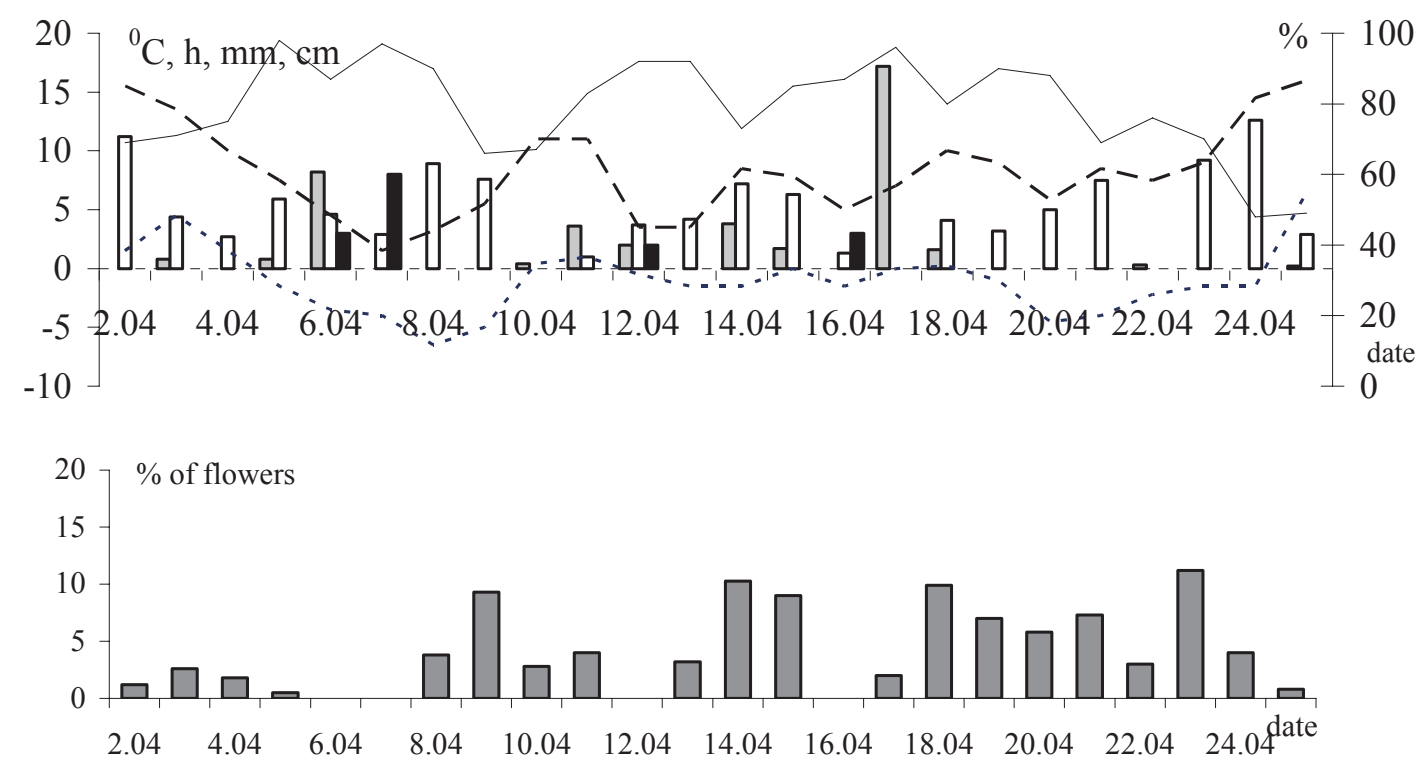

Fig. 5. The seasonal flowering rate of Scilla sibirica L. relative to weather conditions in 1997.

$\square$ - rainfall in mm; - snowfall in $\mathrm{cm}$; $\square$ - sunshine duration in hours;

- air relative humidity in $\% ; \ldots . . . . .-\min$. temp. in ${ }^{\circ} \mathrm{C} ;---\max$. temp. in ${ }^{\circ} \mathrm{C}$

$\square-\%$ of flowers opened on a particular day.
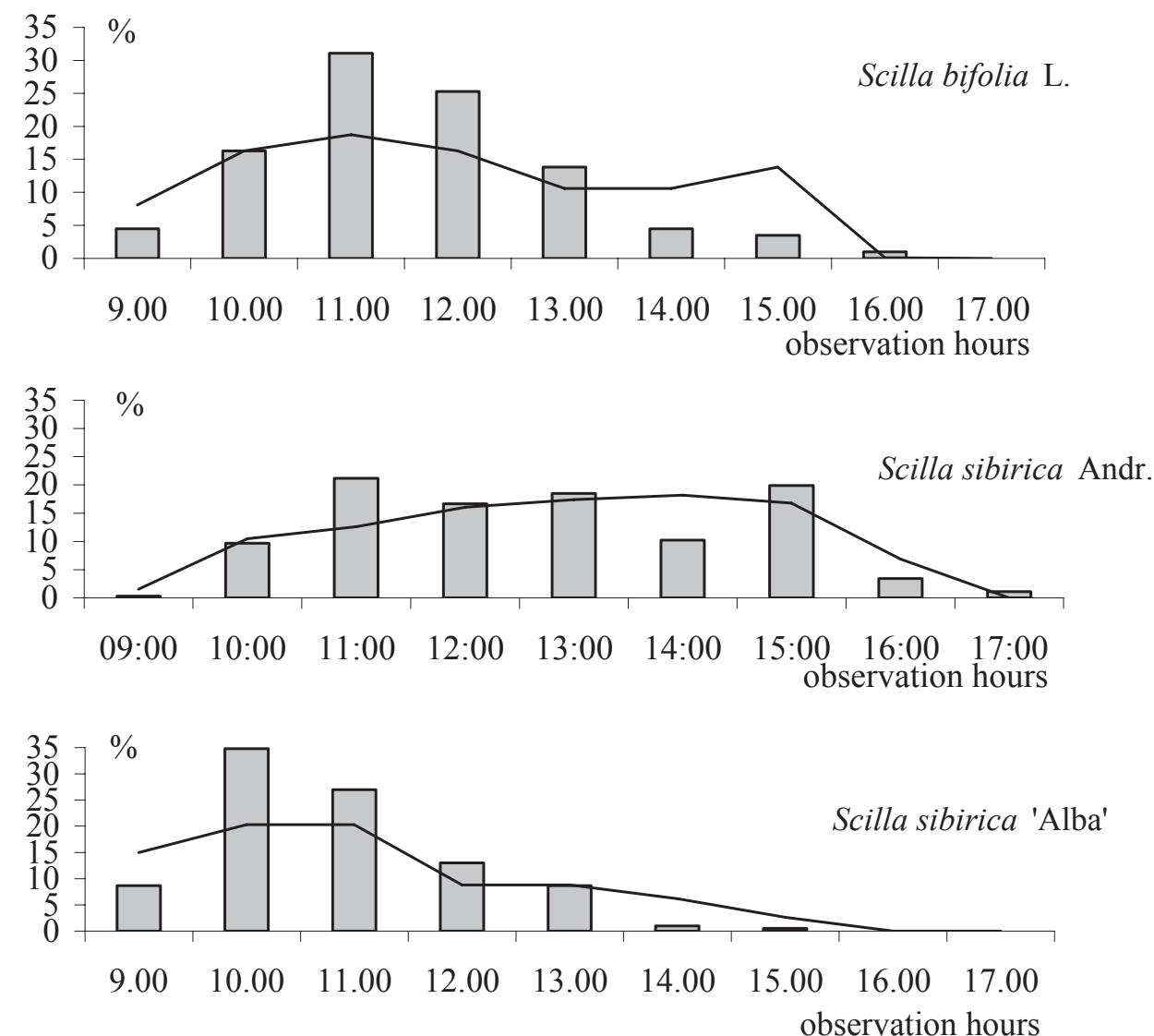

Fig. 6. The daily flowering rate of the studied plant species.

$\square$ - number of flowers opening during 1-hour time periods, expressed as a percentage of all flowers opened during the whole day,

- number of honey bee foragers observed during 1-hour time periods, expressed as a percentage of all foragers observed on a particular day. 


\section{DISCUSSION}

The observed duration of flowering of the squill taxa under study, reaching from 16 up to 24 days, was higher than that reported by P i e t k o v a (1979), which was from 15 to 20 days.

The seasonal rate of honey bee visitation was affected to the greatest extent by weather conditions, primarily temperature. Although worker bees leave the hive for their first foraging trip in the spring already at a temperature of $8^{\circ} \mathrm{C}(\mathrm{Pr} \mathrm{a} \mathrm{b} \mathrm{u} \mathrm{c} \mathrm{ki}, 1998)$, but temperature falls below $10-12^{\circ} \mathrm{C}$ clearly reduced the frequency of bee visitation to the flowers.

The weight of a pair of bee pollen loads produced from the pollen of Scilla sibirica, which was $6.5 \mathrm{mg}$, accounted for a half of the average weight of pollen loads, estimated by Li piński (1982) at 12 $\mathrm{mg}$. The navy blue-violet colour of the pollen loads produced by the bees from the pollen of Scilla sibiri$c a$ was darker than that reported by Hod g e s (1952) who described the colour of Scilla pollen as navy bluegrey. The observations of a wide range of colours of the pollen of Scilla sibirica and Scilla bifolia were consistent with the opinion of Lipins si (1982) who noted that pollen loads from the same plant could differ in their colour, depending on whether a bee gathered pollen from open anthers or extracted it from still immature pollen chambers. Our own observations confirm the fact that honey bees bite through anthers, which is described by Li piński (1982).

Additionally, the observed attempts of insects to open flower buds indicate the great value of Scilla pollen for the Apidae during the early spring period. The fact that pollen food containing protein is consumed quickly by a bee colony in order to raise larvae in early spring would explain why in the literature there is no data on the presence of squill pollen in bee bread stored in hives. The pollen grains of Scilla bifolia observed in the pollen spectrum of willow honey, analysed by W a rako m ska (1987), confirm the attractiveness of this plant to the honey bee, which is also in agreement with what is reported by P i e t k o v (1979) who described numerous visits to the flowers of $S$. $b i$ folia by nectar and pollen foragers. A similar opinion is expressed by Kulije v (1952) who found intensive foraging on various species of Scilla L., among others, S. sibirica. Our observations of bumblebees and wildliving bees foraging on the squill flowers are confirmed by other authors (R u s z k ow ski, 1966, 1971; Ruszkowski and Żak, 1969; Ruszkowski and Biliński, 1986).

Squill found excellent conditions for growth and development on the lawns under the wide-spreading crowns of deciduous trees, which is in agreement with the cultivation recommendations of $\mathrm{Kr}$ a u se (1987, 1992) and O s v a ld (1992). The plants self-propagated from adventitious bulbs, but they also propagated generatively through seeds.

\section{CONCLUSIONS}

1. The span of the flowering period of squill is from the end of March until the middle of May and flowering lasts about three weeks in the case of each taxon.

2. Scilla flowers open between 9.00 am and $5.00 \mathrm{pm}$, with the peak of flower opening between $10.00 \mathrm{am}$ and $3.00 \mathrm{pm}$.

3. There is a variation in the time when the honey bee collects pollen and nectar from the flowers of Scil$l a \mathrm{~L}$. In the morning, before fresh flowers open up, nectar gatherers forage, then pollen foragers until $10.30 \mathrm{am}$, while in the afternoon there is a balance in the harvest of pollen and nectar food.

4. Squill pollen is an attractive protein food for the honey bee, which is manifested in the fact that bees bite through anthers, but also attempt to open flower buds in order to extract pollen grains.

5. The ease of cultivation of squill, its decorative value and attractiveness to pollinating insects speak for the widespread use of these beautiful delicate plants in park plantings and in home gardens.

\section{REFERENCES}

Hodge s D., 1952. The pollen loads of honeybee. Bee Res. Ass., London.

Jabłońs ki B ., 1978. Dbajmy o pożytki wczesnowiosenne. / Let's take care of early spring forage. Pszczelarstwo, 29(3): 5-9 (in Polish).

Jabłoń ski B ., 1986. O pyłku kwiatowym i wydajności pyłkowej roślin. / On floral pollen and pollen productivity of plants. Pszczelarstwo, 37(9): 5-9 (in Polish).

Krause J., 1987. Niskie, ale pięknie kwitnące rośliny cebulowe. Państwowe Wydawnictwo Rolnicze i Leśne, Warszawa (in Polish).

Krause J ., 1992. Rośliny cebulowe. Krajowa Rada Polskiego Związku Działkowców, Warszawa (in Polish).

Kulijev A.M., 1952 Zadaczi izuczienija miedonosnych i piergonosnych rastienij. Izdatielstvo Akad. Nauk. SSSR, Moskwa-Leningrad (in Russian).

Li piński M., 1982, Pożytki pszczele, zapylanie i miododajność roślin. Państwowe Wydawnictwo Rolnicze i Leśne, Warszawa (in Polish).

Marcinkowski J., 1991. Byliny ogrodowe. Państwowe Wydawnictwo Rolnicze i Leśne, Warszawa (in Polish).

Mirek Z., Piękoś-Mirkowa H., Zając A., Zając M., 2002. Flowering plants and pteridophytes of Poland. A checklist. W. Szafer Institute of Botany, Polish Acedemy of Science, Kraków.

O vald Z ., 1992. Leksykon roślin cebulkowych. Oficyna wydawnicza Multico, Warszawa (in Polish). 
Pfosser M., and Speta F., 1999. Phylogenetics of Hyacintheaceae based on plastid DNA sequences. Ann. Missouri Bot. Garden, 86: 852-875.

Pietkov W., 1979. Miedonosni rastienia. Zimizdat., Sofia (in Russian).

Prabuck i J. (red.), 1998. Pszczelnictwo. Wyd. Albatros, Szczecin (in Polish).

Ruszkowski A., 1966. Obserwacje nad porobnicą miodunkową - Anthophora acervorum (L.) Hym., Apidae). / Observations on Anthophora acervorum (L.) Hym., Apidae). Pol. Tow. Entomol. 22: 303-314 (in Polish).

Rus z k ow sk i A ., 1971. Rośliny pokarmowe i znaczenie gospodarcze trzmiela ziemnego - Bombus terrestris (L.) i trzmiela gajowego - B. lucorum (L.). / Forage plants and economic importance of Bombus terrestris (L.) and B. lucorum (L.). Pamiętnik Puławski, 47: 215-250 (in Polish).

Ruszkowski A., Biliński M., 1986. Rośliny pokarmowe oraz znaczenie gospodarcze murarek (Osmia Pz., Hoplitis Klug, Anthocopa Lep. - Hymenoptera, Megachilidae). / Forage plants and economic importance of mason bees (Osmia Pz., Hoplitis Klug, Anthocopa Lep. - Hymenoptera, Megachilidae). Pszczeln. Zesz. Nauk., 38: 171-182 (in Polish).

Ruszkowski A., Żak B., 1969. Rośliny pokarmowe i znaczenie gospodarcze trzmieli z podrodzaju Hortobombus Vogt. / Forage plants and economic importance of bumblebees of the subgenus Hortobombus Vogt. Pszczeln. Zesz. Nauk. 37: 359-381 (in Polish).

S tru miłło J., 1883. Ogrody północne. Nakładem i drukiem Józefa Zawadzkiego, Wilno (in Polish).

Szafer W., Kulczyński S., Pawłowski B., 1969. Rośliny polskie. / Polish plants. Państwowe Wydawnictwo Naukowe, Warszawa (in Polish).

Szla chetka W., 1993. Rośliny cebulowe, bulwiaste i kłączowe stosowane do pędzenia. [In:] H. Chmiel (ed.) Uprawa roślin ozdobnych. Państwowe Wydawnictwo Rolnicze i Leśne, Warszawa (in Polish).
Tyniecki W., 1912. Ogród kwiatowy i drzewa ozdobne. Lwów (in Polish).

Warakomska Z., 1987. Miód i pierzga z pożytku wierzbowego (Salix L.). / Honey and bee bread from willow (Salix L.) as a forage plant. Pszczeln. Zesz. Nauk. 31: 180-181 (in Polish).

Watson, L., Dallwitz, M.J. 1992. The families of flowering plants: descriptions, illustrations, identification, and information retrieval. Version: $20^{\text {th }}$ May 2010. http://delta-intkey.com

\section{Biologia kwitnienia i oblot przez owady zapylające trzech taksonów $\mathrm{z}$ rodzaju Scilla L., (Hyacinthaceae)}

\section{Streszczenie}

Cebulica z rodziny Hyacinthaceae jest drobnocebulową byliną. Badania dotyczące kwitnienia oraz zapylania Scilla sibirica Andr., S. sibirica 'Alba', S. bifolia L. prowadzono w latach 1995, 1997 i 1999 na terenie Ogrodu Botanicznego UMCS w Lublinie. Rośliny kwitły od końca marca do połowy maja. Długość okresu kwitnienia poszczególnych taksonów była podobna i wynosiła średnio 20 dni (Scilla sibirica), $21 \mathrm{dni}$ (S. sibirica 'Alba') i 23 dni (S. bifolia). Otwieranie się pąków kwiatowych rozpoczynało się zawsze około godz. 9:00, i trwało w zależności od taksonu do godz. 15:00 (Scilla sibirica 'Alba'), 16:00 (S. bifolia) i 17:00 (S. sibirica). Kwiaty były odwiedzane przez pszczoły (Apoidea), głównie pszczołę miodną (Apis mellifera L.), trzmiela (Bombus L.) i pszczoły samotnice. Zaobserwowano liczne zbieraczki pszczoły miodnej, które przegryzały ścianki pylników, a nawet starały się otwierać zamknięte jeszcze pąki kwiatowe w celu dostania się do pyłku. 